\title{
MODEL PELAYANAN PUBLIK TERHADAP REFORMASI BIROKRASI
}

\author{
Fitriani Abbas ${ }^{1}$, Anwar Sadat ${ }^{2}$ \\ ${ }^{1}$ Mahasiswa Program Studi Ilmu Pemerintahan \\ ${ }^{2}$ Dosen Ilmu Pemerintahan \\ Fakultas Ilmu Sosial dan Ilmu Politik, Universtas Muhammadiyah Buton \\ Email : fitrianiabbas90@gmail.com
}

\begin{abstract}
Penelitian ini bertujuan untuk mengidentifikasi pelaksanaan reformasi birokrasi, serta menawarkan beberapa solusi untuk perbaikan layanan administrasi perizinan. Penelitian ini menggunakan pendekatan kualitatif dengan jenis penelitian studi kasus instrumental. Lokasi penelitian dilaksanakan di Dinas Perizinan Kabupaten Buton. Teknik pengumpulan data yang digunakan, yaitu: wawancara mendalam, studi dokumen dan observasi. Hasil penelitian menunjukkan bahwa pelaksanaan reformasi birokrasi dalam pelayanan administrasi perizinan, dari aspek Kelembagaan bahwa pelayanan perizinan Kabupaten Buton sudah berbentuk Pelayanan Terpadu Satu Pintu (One Stop Service); aspek Sumber Daya Manusia bahwa kualifikasi pegawai yang ada tidak sesuai dengan kebutuhan organisasi, kedisiplinan dan tanggungjawab pegawai relatif masih rendah. Reformasi tata kelola daerah dimulai dengan bentuk otonomi daerah. Otonomi daerah mewakili kewenangan untuk mengatur bisnis pemerintahan memiliki karakter lokalitas sesuai dengan inisiatif saja sesuai dengan aspirasi masyarakat. Reformasi tata kelola daerah bertujuan untuk menjadi lebih memaksimalkan layanan fungsi lebih memiliki karakter lokalitas publik. Reformasi pelaksanaan tata kelola daerah dapat dilakukan dengan berhubungan dengan konsepsi mengenai pelayanan publik baru yang berorientasi pada pelayanan masyarakat memiliki karakter responsif terhadap berbagai nilai publik dan kepentingan dan juga non diskriminatif.
\end{abstract}

Keyword : Pelayanan Publik, Reformasi Birokrasi, New Public Service 


\section{Pendahuluan}

Pelaksanaan Otonomi Daerah yang telah digulirkan oleh pemerintah sejak tahun 2001 membawa perubahan dalam pelaksanaan pemerintahan di daerah. Salah satu perubahan itu adalah pemberian wewenang yang lebih luas dalam penyelenggaraan beberapa bidang pemerintahan. Seiring dengan bertambah luasnya kewenangan ini, maka aparat birokrasi pemerintahan di daerah dapat mengelola dan menyelenggaraan pelayanan publik dengan lebih baik sesuai dengan kebutuhan masyarakatnya.

Kualitas pelayanan publik hingga saat ini masih diwarnai oleh pelayanan yang sulit untuk diakses, prosedur yang berbelit-belit ketika harus mengurus suatu perijinan tertentu, biaya yang tidak jelas serta terjadinya praktek pungutan liar (pungli), merupakan indikator rendahnya kualitas pelayanan publik di Indonesia. Di mana hal ini juga sebagai akibat dari berbagai permasalahan pelayanan publik yang belum dirasakan oleh rakyat. Di samping itu, ada kecenderungan adanya ketidakadilan dalam pelayanan publik di mana masyarakat yang tergolong miskin akan sulit mendapatkan pelayanan. Sebaliknya, bagi mereka yang memiliki "uang“, dengan sangat mudah mendapatkan segala yang diinginkan. Untuk itu, apabila ketidakmerataan dan ketidakadilan ini terus-menerus terjadi, maka pelayanan yang berpihak ini akan memunculkan potensi yang bersifat berbahaya dalam kehidupan berbangsa. Potensi ini antara lain terjadinya disintegrasi bangsa, perbedaan yang lebar antar yang kaya dan miskin dalam konteks pelayanan, peningkatan ekonomi yang lamban, dan pada tahapan tertentu dapat meledak dan merugikan bangsa Indonesia secara keseluruhan.

Kemudian, terdapat kecenderungan di berbagai instansi pemerintah pusat yang enggan menyerahkan kewenangan yang lebih besar kepada daerah otonom, akibatnya pelayanan publik menjadi tidak efektif, efisien dan ekonomis, dan tidak menutup kemungkinan unit-unit pelayanan cenderung tidak memiliki responsibilitas, responsivitas, dan tidak representatif sesuai dengan tuntutan masyarakat. Banyak contoh yang dapat diidentifikasi; seperti pelayanan bidang pendidikan, kesehatan, transportasi, fasilitas sosial, dan berbagai pelayanan di bidang jasa yang dikelola pemerintah daerah belum memuaskan masyarakat, kalah bersaing dengan pelayanan yang dikelola oleh pihak swasta. Norman Flyn (2017) mengemukakan bahwa pelayanan publik yang dikelola pemerintah secara herarkhis cenderung bercirikan over bureaucratic, bloated, wasteful, dan under performing.

Kejadian-kejadian tersebut lebih disebabkan karena paradigma pemerintahan yang masih belum mengalami perubahan mendasar. Perilaku aparatur negara di lingkungan birokrasi yang masih menempatkan dirinya untuk dilayani bukannya untuk melayani. Seharusnya, dalam era demokratisasi dan desentralisasi saat ini, seluruh perangkat birokrasi, perlu menyadari bahwa pelayanan berarti pula semangat pengabdian yang mengutamakan efisiensi dan keberhasilan bangsa dalam membangun, yang dimanifestasikan antara lain dalam perilaku "melayani, bukan dilayani", "mendorong, bukan menghambat", "mempermudah, bukan mempersulit", "sederhana, bukan berbelitbelit", "terbuka untuk setiap orang, bukan hanya untuk segelintir orang" (Mustopadidjaja, 2012). 
Agar pelayanan publik berkualitas, sudah sepatutnya pemerintah mereformasi paradigma pelayanan publik tersebut. Reformasi paradigma pelayanan publik ini adalah penggeseran pola penyelenggaraan pelayanan publik dari yang semula berorientasi pemerintah sebagai penyedia menjadi pelayanan yang berorientasi kepada kebutuhan masyarakat sebagai pengguna. Dengan begitu, tak ada pintu masuk alternatif untuk memulai perbaikan pelayanan publik selain sesegera mungkin mendengarkan suara publik itu sendiri. Inilah yang akan menjadi jalan bagi peningkatan partisipasi masyarakat di bidang pelayanan publik. Oleh sebab itu reformasi paradigma pelayanan publik tersebut harus dibarengi dengan reformasi penyelenggaraan pemerintahan, dalam konteks otonomi daerah berarti bagaimana mereformasi pola penyelenggaraan pemerintahan daerah.

\section{Metode Penelitian}

Penelitian ini menggunakan pendekatan kualitatif yang berlandasakan phenomenologi. Dengan pendekatan ini akan dilakukan pengamatan yang bersifat holistik dan juga bersifat naturalistik. Sedangkan analisisnya menggunakan pendekatan analisis model interaktif (Miles, Huberman, \& Saldana, 2014). Data utama penelitian ini bersumber dari interview dengan pegawai yang terlibat langsung dalam penyelenggaraan pelayanan publik, dan juga dengan Kepala Dinas Perizinan Pemerintah Kabupaten Buton, serta dengan masyarakat pengguna pelayanan publik yang disediakan oleh Dinas Perizinan Kabupaten Buton. Untuk keperluan triangulasi data utama juga diambil dengan cara observasi. Sedangkan untuk beberapa data tambahan yang tidak tersedia dalam bentuk dokumentasi dilakukan pengambilannya dengan record. Untuk menjamin derajat kepercayaan hasil penelitian ini, dari sejak awal telah diupayakan menjaga keabsahan data yang dikumpulkannya. Teknik yang ditempuh untuk menjaga keabsahan data tersebut antara lain dilakukan dengan cara; a) Melakukan ketekunan pengamatan, b) Melakukan triangulasi, c) Menyelenggarakan pemeriksaan sejawat melui diskusi, d) Menyajikan uraian rinci dan d) Menyelenggarakan auditing.

\section{Pembahasan}

\section{a. Reformasi Pemerintahan Daerah}

Reformasi pemerintahan daerah di Indonesia ditandai dengan lahirnya UU No. 23 Tahun 2014 tentang Pemerintahan Daerah. Reformasi yang dikehendaki di dalam UU tersebut tergolong reformasi yang radikal (radical change) atau drastik (drastic change) dan bukan reformasi yang bersifat gradual (gradual change). Oleh karena itu, konflik, krisis dan goncangan yang menyertai reformasi tersebut lebih besar daripada serangkaian reformasi yang pernah terjadi sebelumnya. Dibandingkan dengan reformasi pemerintahan daerah di berbagai negara berkembang lainnya pun reformasi pemerintahan daerah di Indonesia masih tergolong sangat besar. Reformasi pemerintahan daerah di Indonesia tergolong big bang approach. Dalam melaksanakan tugas dan fungsi sehari-hari dibutuhkan kesungguhan dalam melakukan pekerjaan agar hasil pekerjaan sesuai dengan harapan yang menjadi tujuan organisasi. (Sadat. A, 2017). 
Besarnya perubahan yang terjadi di dalam reformasi pemerintahan daerah tersebut dapat dilihat dari pergeseran paradigma pemerintahan daerah yang terjadi. Paradigma "structural efficiency model" yang menekankan efisiensi dan keseragaman pemerintahan lokal (local government) ditinggalkan dan dianut paradigma "local democracy model" yang menekankan nilai demokrasi dan keberagaman dalam penyelenggaraan pemerintahan daerah. Seiring dengan itu terjadi pula pergeseran dari pengutamaan dekonsentrasi ke pengutamaan desentralisasi (Hoessein, 2001).

Berdasarkan hasil identifikasi, pelaksanaan reformasi birokrasi dengan melihat kelembagaan, sumber daya manusia, serta sistem dan prosedur pada Dinas Perizinan Kabupaten Buton, pelaksanaan reformasi birokrasi tidak berdiri sendiri karena merupakan serentetan dari suatu sebab akibat, sehingga dalam mewujudkan reformasi birokrasi diperlukan pendekatan yang bersifat konfrehensif dan sistemik, hal ini sesuai dengan Dugget yang di kutip Rewansyah (2012) bahwa reformasi birokrasi adalah proses yang dilakukan secara kontinu untuk mendesain ulang birokrasi yang berada di lingkungan pemerintahan. Dari hasil penelitian ini memperlihatkan bahwa pelayanan administrasi perizinan dari beberapa keluhan informan yang paling menonjol bahwa cenderung waktu izin dikeluarkan melebihi dari SOP. Inkonsistensi ini akan mempersulit masyarakat sebagai pengguna layanan, sehingga dapat menjadi kekurangan yang dapat dimanfaatkan oleh pemberi layanan maupun penerima layanan menempuh cara yang bertentangan aturan dan merugikan pihak lain dalam hal ini pengguna layanan.

Temuan penelitian dari kebiasaan aparat menerima insentif akan menyebabkan mereka melakukan tindakan yang diskriminasi terhadap pengguna layanan. Dari beberapa hasil interview dengan informan menunjukkan bahwa penggunaan perantara dengan adanya pemberian insentif akan mempermudah pengguna layanan untuk mencapai apa yang diinginkan akan tetapi pada sisi yang lain akan merugikan masyarakat sesama pengguna layanan yang tidak menggunakan perantara. Hal ini senada dengan yang ungkapan yang menyatakan bahwa esensi pelayanan publik mengacu pada insentif merupakan faktor penentu bagi birokrasi bawahan (street level birokrasi) dalam penciptaan kepuasan layanan kepada pelanggan (Im, 2014).

Permasalahan yang kedua, dari segi demand bahwa pemerintah daerah menghadapi permintaan yang terus menerus meningkat terhadap pemenuhan barang dan jasa publik, yang diartikan sebagai urban services. Transportasi massal, pengendalian banjir, dan pemeliharaan kebersihan atau lingkungan merupakan contoh urban services yang kebutuhannya semakin meningkat.

Kedua permasalahan tersebut merupakan fenomena government growth yang dihadapi banyak pemerintah daerah, jika fenomena ini tidak bisa diantisipasi secara tepat, maka proses pembangunan pun akan mengalami hambatan. Antisipasi yang dilakukan tersebut dimaksudkan demi tercapainya pemerintah yang mampu memberikan inovasi pelayanan yang lebih baik pada masyarakat.

\section{b. Konsepsi Reinventing Government Management}

Model New Public Management mengalami beberapa bentuk inkarnasi, misalnya munculnya konsep "managerialism"; "market-based public administration"; "post- 
bureaucratic paradigm"; dan "entrepreneurial government" (Osborne and Gaebler, 1992). New Public Management berfokus pada manajemen sektor publik yang berorientasi pada kinerja, bukan berorientasi kebijakan. Penggunaan paradigma New Public Management tersebut menimbulkan beberapa konsekuensi bagi pemerintah di antaranya adalah tuntutan untuk melakukan efisiensi, pemangkasan biaya (cost cutting), dan kompetisi tender.

Menurut Osborne dan Gaebler ada sepuluh prinsip reinventing government management, yaitu yang pertama adalah pemerintahan katalis yang memisahkan fungsi pemerintah sebagai pengarah dan fungsi sebagai pelaksana. Kedua pemerintah milik masyarakat, yaitu mengalihkan wewenang kontrol yang dimiliki pemerintah ke tangan masyarakat. Ketiga, pemerintah yang kompetitif, yang mensyaratkan persaingan di antara para penyampai jasa atau pelayanan untuk bersaing berdasarkan kinerja dan harga. Keempat, pemerintah yang digerakkan oleh misi, yaitu mengubah organisasi yang digerakkan oleh peraturan menjadi organisasi yang digerakkan oleh misi. Kelima, pemerintah yang berorientasi hasil, yaitu pemerintah yang result-oriented mengubah fokus dari input menjadi akuntabilitas pada hasil. Keenam, pemerintah berorientasi pada pelanggan, yaitu pemerintah yang lebih memenuhi kebutuhan pelanggan, bukan kebutuhan birokrasi. Ketujuh, pemerintahan wirausaha, yaitu pemerintah yang berusaha memfokuskan energinya bukan sekedar untuk menghabiskan anggaran, tetapi juga menghasilkan uang. Kedelapan, pemerintah antisipatif, yaitu pemerintah yang berupaya mencegah daripada mengobati. Kesembilan, pemerintah desentralisasi, yaitu pemerintah yang dijalankan dari hierarkhi menuju partisipatif dan tim kerja. Kesepuluh, pemerintah berorientasi pada (mekanisme) pasar, yaitu pemerintah yang mampu mengadakan perubahan dengan mekanisme pasar (sistem insentif) dan bukan dengan mekanisme administratif (sistem prosedur dan pemaksaan).

Relevansi konsep reinventing government management terhadap upaya pengembangan aparatur dan mekanisme penyelenggaraan aparatur pemerintah daerah sangat banyak. Antara lain adanya komitmen yang kuat untuk melakukan reformasi birokrasi di lingkungan pemerintah daerah, disertai perlu adanya visi dan misi yang jelas dari pimpinan untuk melakukannya. Dengan kekuatan visi dan misi yang dimiliki oleh pimpinan diharapkan mampu menyeimbangkan gaya dan pola manajemen dengan perubahan dan dinamika lingkungan yang semakin kompleks.

Hal lain yang sangat esensial dalam reinventing government management ini adalah berbagai mekanisme penyediaan infrastruktur dan fasilitas umum yang seharusnya ditangani oleh pemerintah daerah secara bertahap dialihkan dengan memberdayakan masyarakat. Dengan demikian keterbatasan pendanaan dan sebagainya dapat tertutupi dengan pola seperti ini.

\section{c. Konsep dan Dinamika Pelayanan Publik}

Pelayanan publik merupakan produk birokrasi publik yang diterima oleh warga pengguna maupun masyarakat secara luas. Karena itu menurut pelayanan publik dapat didefinisikan sebagai serangkaian aktivitas yang dilakukan oleh birokrasi publik untuk memenuhi kebutuhan warga pengguna. Pengguna yang dimaksud disini adalah warga 
negara yang membutuhkan pelayanan publik, seperti pembuatan KTP, IMB, akte kelahiran, sertifikat tanah dan lain sebagainya.

Masyarakat setiap waktu selalu menuntut pelayanan publik yang berkualitas dari birokrasi pemerintah, meskipun tuntutan tersebut sering tidak sesuai dengan harapan mereka, karena secara empiris pelayanan publik yang terjadi selama ini masih terkesan berbelit-belit, lambat, mahal dan melelahkan. Kecenderungan seperti itu terjadi karena masyarakat masih diposisikan sebagai pihak yang "melayani", bukan yang "dilayani". Oleh sebab itu pada saat ini kebutuhan mendesak yang perlu dilakukan oleh birokrasi pemerintah adalah melakukan reformasi pelayanan publik dengan mengembalikan dan mendudukkan "pelayan" dan yang "dilayani" ke pengertian yang sesungguhnya.

Berkaitan dengan pelayanan publik dalam rangka mewujudkan kesejahteraan rakyat, birokrasi publik tentunya memberikan kontribusi yang sangat besar, karena semua yang termasuk dalam lingkup penyelenggaraan negara tidak terlepas dari konteks public service dan public affairs (Fukuyama, 2017; Hidayat \& Nasution, 2017; Mulyani, Sinarwati, Yuniarta, \& AK, 2017; Needham \& Dickinson, 2017). Barang dan jasa publik hendaknya dapat dikelola secara efisien dan efektif. Sedangkan konsekuensi dari pengelolaan tersebut menjadi tanggung jawab birokrasi. Dengan demikian peran pemerintah yang sangat strategis tersebut akan banyak ditopang oleh bagaimana birokrasi publik mampu melaksanakan tugas dan fungsinya.

Dengan adanya kontrol dari masyarakat pelayanan publik akan lebih baik, karena mereka akan memiliki komitmen yang lebih baik, lebih peduli dan lebih kreatif dalam memecahkan masalah. Pelayanan yang diberikan oleh birokrat ditafsirkan sebagai kewajiban, bukan hak karena mereka diangkat oleh pemerintah untuk melayani masyarakat, oleh karena itu harus dibangun komitmen yang kuat untuk melayani sehingga pelayanan akan dapat menjadi lebih responsif terhadap kebutuhan masyarakat dan dapat merancang model pelayanan yang lebih kreatif serta lebih efisien.

Sementara itu dalam konteks desentralisasi (otonomi daerah), Mohamad (2003) mengatakan bahwa pelayanan publik seharusnya menjadi lebih responsif terhadap kepentingan publik. Paradigma pelayanan publik berkembang dari pelayanan yang sifatnya sentralistik ke pelayanan yang lebih memberikan fokus pada pengelolaan yang berorientasi kepuasan pelanggan (customer-driven government) dengan ciri-ciri: (a) lebih memfokuskan diri pada fungsi pengaturan melalui berbagai kebijakan yang memfasilitasi berkembangnya kondisi kondusif bagi kegiatan pelayanan kepada masyarakat, (b) lebih memfokuskan diri pada pemberdayaan masyarakat sehingga masyarakat mempunyai rasa memiliki yang tinggi terhadap fasilitas-fasilitas pelayanan yang telah dibangun bersama, (c) menerapkan sistem kompetisi dalam hal penyediaan pelayanan publik tertentu sehingga masyarakat memperoleh pelayanan yang berkualitas, (d) terfokus pada pencapaian visi, misi, tujuan dan sasaran yang berorientasi pada hasil (outcomes) sesuai dengan masukan yang digunakan, (e) lebih mengutamakan apa yang diinginkan oleh masyarakat, (f) pada hal tertentu pemerintah juga berperan untuk memperoleh pendapat dari masyarakat dari pelayanan yang dilaksanakan, (g) lebih mengutamakan antisipasi terhadap permasalahan pelayanan, (h) lebih mengutamakan desetralisasi dalam pelaksanaan pelayanan, dan (i) menerapkan sistem pasar dalam memberikan pelayanan. 
Pada dasarnya pemerintah telah melakukan berbagai upaya agar menghasilkan pelayanan yang lebih cepat, tepat, manusiawi, murah, tidak diskriminatif, dan transparan. Namun, upaya-upaya yang telah ditempuh oleh pemerintah nampaknya belum optimal. Salah satu indikator yang dapat dilihat dari fenomena ini adalah pada fungsi pelayanan publik yang banyak dikenal dengan sifat birokratis dan banyak mendapat keluhan dari masyarakat karena masih belum memperhatikan kepentingan masyarakat penggunanya. Kemudian, pengelola pelayanan publik cenderung lebih bersifat direktif yang hanya memperhatikan/ mengutamakan kepentingan pimpinan/organisasinya saja. Masyarakat sebagai pengguna seperti tidak memiliki kemampuan apapun untuk berkreasi, suka tidak suka, mau tidak mau, mereka harus tunduk kepada pengelolanya. Seharusnya, pelayanan publik dikelola dengan paradigma yang bersifat supportif di mana lebih memfokuskan diri kepada kepentingan masyarakatnya, pengelola pelayanan harus mampu bersikap menjadi pelayan yang sadar untuk melayani dan bukan dilayani.

Hasil pengamatan menunjukkan bahwa kedisiplinan dan tanggungjawab pegawai

Dinas Perizinan Kabupaten Buton relatif masih rendah, petugas loket sering meninggalkan tempat pada jam kantor, terutama apabila pengunjung sepi, pengamatan terhadap perilaku pegawai saat berhubungan dengan masyarakat pengguna layanan menunjukkan sikap kurang perhatian, seringkali mereka mengerjakan hal lain saat berhadapan dengan pemohon, misalnya menerima hubungan telepon pribadi atau berbicara dengan rekan kerja mengenai hal di luar tugas, hal ini menunjukkan sikap rendahnya perhatian pegawai terhadap pemohon atau warga msyarakat yang di layani.

Dari hasil pemaparan pengembangan kapasitas melalui diklat teknis tersebut dapat ditarik kesimpulan bahwa intensitas pengembangan kapasitas aparat Dinas Perizinan Kabupaten Buton melalui diklat teknis masih rendah dengan rata-rata pelaksanaan hanya sekali dalam setahun dengan kuantitas yang mengikuti rata-rata 1 setiap Diklat. Dalam hal penugasan selama ini pemberian penugasan terhadap lingkup Dinas Perizinan Kabupaten Buton tetap disesuaikan dengan tugas pokok dan fungsi aparatur yang bersangkutan. Hal ini tidak terlepas dari tugas dan fungsi yang ada dalam Dinas yang banyak bersifat teknis yang memang tidak memungkinkan bagi aparatur dari satu bidang untuk mewakili bidang lain. Adanya keterkaitan penugasan dengan tupoksi menyebabkan terdapat bidang teknik tertentu yang mendapatkan porsi penugasan yang lebih banyak di banding dengan bidang lainnya, kenyataan ini menyebakan kurang meratanya pengetahuan dan keterampilan di antara aparatur pemerintah daerah.

\section{d. Reformasi Paradigma Pelayanan Publik}

Secara teoritis, Denhardt and Denhardt (2000) mengatakan bahwa telah terjadi pergeseran paradigma pelayanan publik dari model administrasi publik tradisional (old public administration) ke model manajemen publik baru (new public management) dan akhirnya menuju model pelayanan publik baru (new public service) seperti terlihat pada tabel berikut ini. 


\section{Pergeseran Paradigma Model Pelayanan Publik}

\begin{tabular}{|c|c|c|c|}
\hline Aspek & $\begin{array}{c}\text { Old Public } \\
\text { Administration }\end{array}$ & $\begin{array}{l}\text { New Public } \\
\text { Manajemen }\end{array}$ & New Public Service \\
\hline Dasar Teori & Teori Politik & Teori Ekonomi & Teori Demokrasi \\
\hline $\begin{array}{c}\text { Konsep } \\
\text { Kepentingan } \\
\text { Publik }\end{array}$ & $\begin{array}{c}\text { Kepentingan publik } \\
\text { adalah sesuatu yang } \\
\text { didefinisikan secara } \\
\text { politik dan yang } \\
\text { tercantum dalam } \\
\text { aturan } \\
\end{array}$ & $\begin{array}{c}\text { Kepentingan publik } \\
\text { mewakili agregasi } \\
\text { dan kepentingan } \\
\text { individu }\end{array}$ & $\begin{array}{l}\text { Kepentingan publik } \\
\text { adalah hasil dari } \\
\text { agregasi dialog tentang } \\
\text { berbagai nilai }\end{array}$ \\
\hline $\begin{array}{l}\text { Kepada Siapa } \\
\text { Birokrasi harus } \\
\text { Bertanggung } \\
\text { jawab }\end{array}$ & Klien dan Pemilih & Pelanggan & Warganegara \\
\hline Peran Pemerintah & Pengayuh (rowing) & $\begin{array}{l}\text { Mengarahkan } \\
\text { steering }\end{array}$ & $\begin{array}{c}\text { Menegosiasikan dan } \\
\text { mengeloborasi berbagai } \\
\text { kepentingan } \\
\text { warganegara dan } \\
\text { kelompok komunitas }\end{array}$ \\
\hline Akuntabilitas & $\begin{array}{l}\text { Menurut hierarki } \\
\text { administratif }\end{array}$ & $\begin{array}{c}\text { Kehendak pasar yang } \\
\text { merupakan keinginan } \\
\text { pelanggan }\end{array}$ & $\begin{array}{c}\text { Multi aspek; akuntabel } \\
\text { pada hukum, nilai } \\
\text { komunitas, norma } \\
\text { politik, standar } \\
\text { profesional, } \\
\text { kepentingan warga } \\
\text { negara }\end{array}$ \\
\hline
\end{tabular}

Sumber : Denhardt and Denhardt (2000).

Dalam model new public service, berlandaskan teori demokrasi yang mengajarkan adanya egaliter dan persamaan hak diantara warga negara. Dalam model ini kepentingan publik dirumuskan sebagai hasil dialog dari berbagai nilai yang ada di dalam masyarakat. Kepentingan publik bukan dirumuskan oleh elit politik seperti yang tertera dalam aturan. Birokrasi yang memberikan pelayanan publik harus bertanggung jawab kepada masyarakat secara keseluruhan. Peran pemerintah adalah melakukan negosiasi dan menggali berbagai kepentingan dari warga negara dan berbagai kelompok komunitas yang ada. Dalam model ini birokrasi publik bukan hanya sekedar harus akuntabel pada berbagai aturan hukum, melainkan juga harus akuntabel pada nilai-nilai yang ada dalam masyarakat, norma politik yang berlaku, standar profesional dan kepentingan warga negara. Itulah serangkaian konsep pelayanan publik yang ideal masa kini di era demokrasi.

Dasar teoritis pelayanan publik yang ideal menurut paradigma new public service adalah bahwa pelayanan publik harus responsif terhadap berbagai kepentingan dan nilainilai publik. Tugas pemerintah adalah melakukan negosiasi dan mengelaborasi berbagai kepentingan warga negara. Dengan demikian karakter dan nilai yang terkandung di dalam pelayanan publik harus berisi preferensi nilai-nilai yang ada di dalam masyarakat. 
Karena masyarakat bersifat dinamis, maka karakter pelayanan publik juga harus selalu berubah mengikuti perkembangan masyarakat.

Disamping itu pelayanan publik model baru harus bersifat non-diskriminatif sebagaimana dimaksud oleh dasar teoritis yang digunakan, yaitu teori demokrasi yang menjamin adanya persamaan tanpa membedakan asal usul, suku, ras, etnik, agama, dan latar belakang kepartaian. Ini berarti setiap warga negara diperlakukan secara sama ketika berhadapan dengan birokrasi publik dalam menerima layanan sepanjang syarat-syarat yang dibutuhkan terpenuhi. Hubungan yang terjalin antara birokrat publik dengan warga negara adalah hubungan impersonal sehingga terhindar dari sifat nepotisme dan primordialisme. Model pelayanan publik seperti ini diharapkan dapat menjadi suatu model yang sesuai dengan harapan masyarakat.

\section{Kesimpulan}

Reformasi pemerintahan daerah di Indonesia tergolong dalam konsepsi reformasi yang bersifat radikal (radical change) atau drastik (drastic change) dan bukan reformasi yang bersifat gradual (gradual change). Penelitian ini diarahkan untuk mengidentifikasi bentuk reformasi birokrasi dalam pelayanan publik, merupakan salah satu jenis pelayanan berbentuk PTSP yaitu pelayanan perizinan di Kabupaten Buton. Setelah teridentifikasi bentuk pelaksanaan reformasi birokrasi, maka dilakukan analisis untuk menemukan bagaimana reformasi birokrasi tersebut. Adapun secara garis besar kesimpulan yang dihasilkan dari penelitian ini bahwa dari aspek kelembagaan, sumber daya manusia, serta sistem dan prosedur belum berjalan secara optimal. Di dalam reformasi pemerintahan daerah tersebut, terjadi pergeseran paradigma pemerintahan daerah. Paradigma "structural efficiency model" yang menekankan efisiensi dan keseragaman pemerintahan lokal (local government) ditinggalkan dan dianut paradigma local democracy model yang menekankan nilai demokrasi dan keberagaman dalam penyelenggaraan pemerintahan daerah. Seiring dengan itu terjadi pula pergeseran dari pengutamaan dekonsentrasi ke pengutamaan desentralisasi.

Untuk melakukan reformasi manajemen pemerintahan guna meningkatkan pelayanan publik menjadi lebih baik, dapat diupayakan melalui program reinventing government management. Pada dasarnya konsepsi mengenai reinventing government management bertujuan untuk memperbaiki efisiensi, efektivitas dan kinerja pemerintahan serta memberdayakan masyarakat. Sementara itu terjadi pula pergeseran paradigma pelayanan publik dari model administrasi publik tradisional (old public administration) ke model manajemen publik baru (new public management) dan akhirnya menuju model pelayanan publik baru (new public service).

Berdasarkan temuan penelitian penulis di Kabupaten Buton merupakan masyarakat transisi (prismatic society) berada diantara masyarakat tradisional dan modern yang pada dasarnya mengetahui adanya aturan pembayaran standar pengurursan perizinan namun dibayarkan melebihi standar yang telah ditetapkan. Sehingga perbuatan masyarakat tersebut yang turut mempengaruhi reformasi birorkrasi dimana dalam tulisan ini diistilahkan sebagai "bidah ragulasi". Sesuai dengan kebutuhan masyarakat yang makin meningkat, tuntutan yang lebih terbuka, serta perkembangan globalisasi yang memicu 
peningkatan yang lebih cepat lagi dalam kebutuhan dan tuntutan akan layanan publik, maka paradigma new public service yang menghendaki pelayanan publik harus responsif terhadap berbagai kepentingan dan nilai-nilai publik serta bersifat non-diskriminatif.

\section{Referensi}

Dwiyanto, Agus, 2002, Reformasi Tata Pemerintahan dan Otonomi Daerah, Pusat Studi Kependudukan dan Kebijakan UGM, Yogyakarta.

Flyn, Norman. 2017. Public Sector Management, Harvester Wheatsheaf, London.

Fukuyama, F. (2017). State building: Governance and world order in the 21st century. Profile Books

Hidayat, S., \& Nasution, I. (2017). Pelayanan Pencegahan dan Pemadam Kebakaran Pemerintah bagi Masyarakat dalam Mengatasi Musibah. JPPUMA: Jurnal Ilmu Pemerintahan dan Sosial Politik Universitas Medan Area, 1(2), 16.

Im, T. (2014). Bureaucratic power and government competitiveness. In The Korean Government and Public Policies in a Development Nexus, Volume 1 (hal. 55-75). Springer.

Hoessein, B. 2001. "Prospek Resolusi Kebijakan dan Implementasi Otonomi Daerah dari Sudut Pandang Hukum Tata Negara"; Seminar dan Lokakarya Nasional Strategi Resolusi Kebijakan dan Implementasi Otonomi Daerah Dalam Kerangka Good Governance; Lembaga Administrasi Negara, Jakarta.

Mohamad, Ismail, 2003, Aktualisasi Pelayanan Prima Dalam Kapasitas PNS sebagai Abdi Negara dan Abdi Masyarakat, Makalah, disampaikan dalam Diskusi Panel Optimalisasi Peran PNS pada Pelaksanaan Tugas Pokok sebagai Abdi Negara dan Abdi Masyarakat, yang diselenggarakan oleh Unit KORPRI POLRI Pusat, pada tanggal 23 Oktober 2003, Jakarta.

Mustopadidjaja AR, 2012, Kompetensi Aparatur Dalam Memikul Tanggung Jawab Otonomi Daerah Dalam Sistem Administrasi Negara Kesatuan Republik Indonesia, Ceramah Perdana Pada Program Magister Manajemen Pembangunan Daerah, Kerjasama STIA-LAN, Pemerintah Prov. Kaltim, dan Universitas Mulawarman, 15 Januari, 2002. Samarinda.

Needham, C., \& Dickinson, H. (2017). "Any one of us could be among that number": Comparing the Policy Narratives for Individualized Disability Funding in Australia and England. Social Policy \& Administration.

Sadat, A. (2017). Kinerja Bagian Hukum Dan Organisasi Sekretariat Daerah Kota Baubau Dalam Era Otonomi. Sang Pencerah: Jurnal Ilmiah Universitas Muhammadiyah Buton, 3(1), 1-15.

Osborne, David \& Gaebler, T. 1992. Reinventing Government : How The Entrepreneurial Spirit is Transforming The Public Sector. Reading, Massachussetts : A William Patrick Book. 